\title{
Age of the Oil in Southern Oklahoma Fields
}

BY SIDNFY POWERS, PH. D., WASHINGTON, D. C.

(New York Meeting, February, 1918)

\section{INTRODUCTION}

Since the opening of the Wheeler oil and gas field in Carter County and the discovery of oil near Lawton, Comanche County, Okla., in 1904, interest has been aroused regarding the origin of the oil in the Permian "Red Bed" region which lies between the Wichita and Arbuckle Mountains on the north and the Red River on the south. The later development of the Healdton, Loco, Duncan, Fox, and Graham fields south and west of the Arbuckle Mountains has brought the region into prominence. Recent discoveries of Ordovician and of Pennsylvanian fossils in wells in the Healdton field and of Pennsylvanian fossils in the Fox and Graham fields are of such importance from a scientific and a commercial standpoint that the occurrences and the problems arising therefrom are here briefly described.

Producing oil and gas sands in the southern Oklahoma fields, with the exception of those in the Cretaceous and underlying rocks in the vicinity of Madill, Marshall County, are associated with the Permian "Red Beds" or with the underlying Paleozoic strata. In the two fields farthest south of the Arbuckle Mountains, Healdton and Loco, production has been entirely confined to sands at depths of 700 to $1400 \mathrm{ft}$. (213 to $416 \mathrm{~m}$.) and only recently has a producing sand as deep as 1860 ft. $(567 \mathrm{~m} .)^{1}$ been encountered. These sands are found near and below the base of the red rocks and were supposed by Wegemann and Heald ${ }^{2}$ to belong in large part to the basal Permian, Wichita formation, or to the immediately underlying formations. Fossils in the blue shales and in the limestones associated with the deeper sands now prove them to be Pennsylvanian and all the producing sands at Healdton are found to be of this age. In the fields nearest the Arbuckle Mountains, the Wheeler sands at a depth of about $700 \mathrm{ft}$. (213 m.) appear to be of Permian age,

1 The general altitude of the country varies from about $850 \mathrm{ft}$. $(259 \mathrm{~m}$,) at Healdton to $1150 \mathrm{ft}$. $(350 \mathrm{~m}$.) at Duncan. (A sand of Ordovician age has been discovered at a depth of $2700 \mathrm{ft}$. since the above was written.)

${ }^{2}$ C. H. Wegemann and K. C. Heald: Healdton Oil Field, Carter County, Oklahoma. $U, S$. Geological Survey Bulletin 621B (1915). 


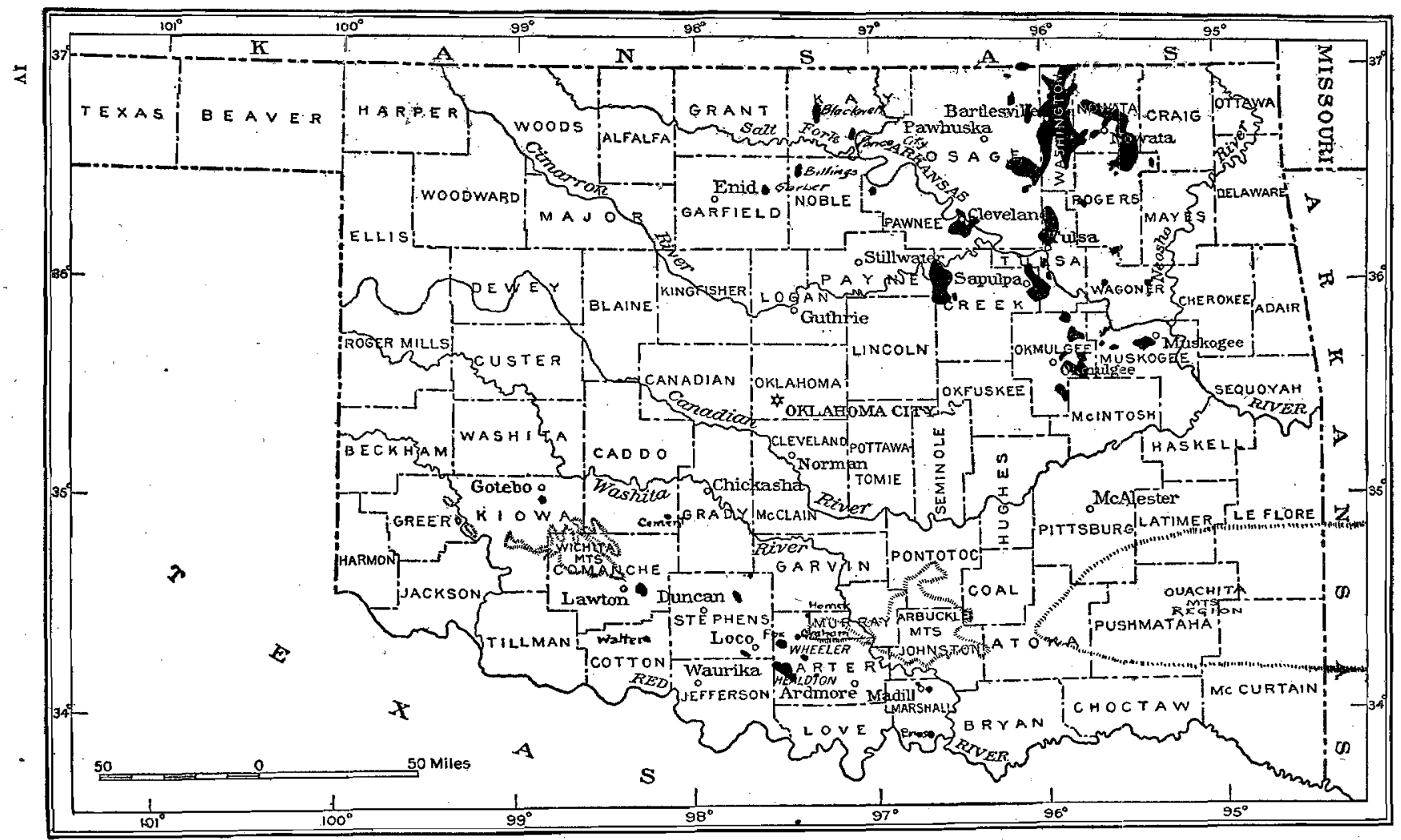

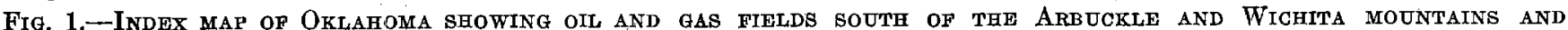
MANY OF THOSE IN THE REMAINDER OF THE STATE. (From U. S. Geological Survey, Bulletin No. 621.) 
the Fox sands at depths of about $2000 \mathrm{ft}$. $(609 \mathrm{~m}$.) are definitely pre-Permian, and the Graham sands are both Permian and Pennsylvanian, while the Lawton field has three Permian sands, the deepest of which is $800 \mathrm{ft}$. $(243 \mathrm{~m}$.) below the surface.

\section{Grologic History}

Southern Oklahoma comprises the Wichita, Arbuckle, and Ouachita Mountains (Fig. 1), the "Red Bed" country south of the first two mountain ranges, and the Cretaceous sand and limestone country southeast of the Arbuckles and south of the Ouachita Mountains.

The geological history of southern Oklahoma may be deciphered as far back as pre-Cambrian time for granite of this age formed the surface on which were deposited sandstones, limestones and shales (limestones predominating) of Lower Paleozoic age. About $8000 \mathrm{ft}$. $(2438 \mathrm{~m}$.) of sediments ranging in age from Middle Cambrian to Devonian are found in the Arbuckle Mountains. While deposition of shales and some limestones took place over part of this region in Mississippian time, the great thickness $(10,000 \mathrm{ft}$. or more) of blue shales which occur on the flanks of the Arbuckle Mountains were deposited unconformably on the older sediments during the Pennsylvanian period. Following the mountainbuilding movement at the close of the Pennsylvanian, about $2500 \mathrm{ft}$., or more, of Permian red sandstones and shales with basal limestone conglomerates were laid down on the south and west sides of the Arbuckle Mountains. After the peneplanation of the region, Cretaceous sandstone beds were deposited southeast of the Arbuckle Mountains.

\section{Diastrophism}

Diastrophism in the region is connected with two disturbances, one in the late Paleozoic, the other in mid-Tertiary time.

The first disturbance was a continuation of the Appalachian mountain-building movement west of the Mississippi River. It commenced with the "Ouachita disturbance" of Schuchert in the Ouachita and in the Arbuckle Mountains during the close of the Mississippian, at which time the major Arbuckle uplift must have taken place. A second folding, the Appalachian revolution, at the close of the Pennsylvanian, further elevated and folded the Wichita, Arbuckle, and Ouachita Mountains, the Criner Hills and the buried Healdton Hills, to be referred to later. It is not improbable that this Appalachian revolution with the elevation of the Paleozoic geosynclinal prisms gave rise to the numerous anticlines of small vertical displacement which have produced so much petroleum in Oklahoma and Kansas north of the Arbuckle Mountains. In the closing stages of the Appalachian movement, the Permian and underlying 
sediments were folded into their present attitude, giving rise to the Healdton, Loco, Lawton, and other anticlines. The location of the Healdton uplift was above the buried Healdton Hills. In some cases, the younger anticlines may have been formed over uplifts of late Pennsylvanian age, but in the majority of cases the anticlines were formed where there had been no late Pennsylvanian uplift.

The second disturbance, during the late Miocene (?), gave rise to the anticlines of small lateral extent and small displacement in the Cretaceous of southeastern Oklahoma and north Texas and to the Sabine uplift in Louisiana. On the peneplain developed after this uplift were laid the gravel deposits, consisting of quartz and chert pebbles, which are found throughout northern Louisiana and east Texas. ${ }^{3}$

\section{Permian "Red Beds"}

Forming a marked lithologic contrast to the older Paleozoic limestones and to the blue shales and occasional sandstones of the Pennsylvanian in and around the Arbuckle Mountains, the Permian sediments on the south and west of these mountains are composed at the base of limestones, limestone conglomerates, ferruginous and asphaltic sandstones, overlain by green and yellow sandstones and clays with a very thick series of red clays and sandstones and occasional selenite-bearing clays at the present top. Over $1600 \mathrm{ft}$. $(487 \mathrm{~m}$.) of red beds are recorded in some well logs.

Against the Arbuckle and Wichita Mountains, the Permian basal limestones, dipping away from the mountains at angles of $6^{\circ}$ to $8^{\circ}$, rest on upturned and truncated older rocks ranging in age from pre-Cambrian to Pennsylvanian. The unconformity can be traced from the Arbuckle Mountains to the Criner Hills, but at the latter locality, near Brock, the unconformity becomes very slight.

A complete Permian section, as eompiled from all the data available, gives the stratigraphy as follows:

Top $400+f t$. Red clay forming western prairies.

$550+\mathrm{ft}$. Red sandstone.

$70 \mathrm{ft}$. White calcareous sandstones and yellow selenite-bearing clays (at Fox).

$600+\mathrm{ft}$. Red sandstone, upper beds being resistant to erosion.

$300+$ ft. Pale greenish, yellowish and red sandstone (at Healdton).

3 These gravel deposits are probably the peneplain equivalent of the Pliocene Citronelle formation in Louisiana (G. C. Matson: Pliocene Citronelle Formation of the Gulf Coastal Plain; E. W. Berry: Flora of the Citronelle Formation. U.S. Geological Survey Professional Paper 98L (1916)) and of the Lissie gravel of Texas (A. Deussen: Geology and Underground Waters of the Southeastern Part of the Texas Coastal Plain.- U. S. Geological Survey Water Supply Paper 335 (1914), 78). 
Base $80 \mathrm{ft}$. Basal limestone conglomerate, limestone, limonitic calcareous sandstone, forming foothills of Arbuckle Mountains.

Total $2000+$ ft.

Conditions of deposition of the Permian are not well understood. It has been argued that the red color represents maturely weathered material in which the oxide of iron was dehydrated before deposition. ${ }^{4}$ On the other hand, evidences of contemporaneous life consists of bones of land animals including amphibians and primitive reptiles, fish remains including sharks' teeth, ${ }^{5}$ leaf impressions and silicified wood, the latter being especially abundant near the base of the formation. The sediments themselves, with the exception of the beds of almost pure limestone at the base of the formation near Poolville (Elk) and Woodford, and of arkose derived from the Tishomingo granite, exposed near Brock, show abundant cross-bedding, current marks, and both normal and torrential ripple marks, indicating shallow water or subaerial deposition. Broad flood plains with intermittent, overloaded streams transporting sand and clay from the uplands on the north, occasional playa lakes and incursions of a shallow sea, with a climate such as could support a limited tree growth on both the uplands and the flood plains, are supposed to represent conditions during Permian deposition.

\section{Sources of Petroleum}

Life of such a character as could give rise to accumulations of petroleum was entirely absent from the region during Permian deposition and it is therefore obvious that the petroleum now found in the Permian rocks must have been derived from some pre-Permian source. The quality of Permian oil is in general poorer than that of Pennsylvanian oil owing, doubtless, to contamination and deterioration by sulphur-bearing waters during irrigation.

Bitumen has for a number of years been mined in the Arbuckle Mountains in the vicinity of Gilsonite and of Dougherty, Murray County, and "shows" of heavy oil have been found in wells drilled in the older Paleozoic rocks to such an extent that further drilling is now being carried on. As described in the Tishomingo folio, ${ }^{6}$ bitumen has been mined in the Franks conglomerate (Pennsylvanian), in the Viola limestone (Ordovic-

4 The origin of the red color is discussed in the following references:

C. W. Tomlinson: The Origin of Red Beds, Journal of Geology (1916), $\overline{\mathbf{2 4}}, \mathbf{1 5 3 - 1 7 9}$, 239-253.

C. H. Wegemann: Anticlinal Structure in Parts of Cotton and Jefferson Counties, Oklahoma. U. S. Geological Survey Bulletin 602 (1915), 20-24.

5 The animal and fish remains have been found south of the region under discussion.

- U. S. Geological Survey, Folio No. 98 (1903). 
ian), and in both the middle and upper sandstone members of the Simpson formation (Ordovician). That the bitumen was apparently introduced into these rocks before late Pennsylvanian time is shown by the presence of boulders of bituminous Simpson formation (Ordovician) sandstone in the Franks conglomerate (Pennsylvanian). ${ }^{7}$

Bitumen also occurs in abundance in certain horizons of the Glenn formation (Pennsylvanian) south of the Arbuckle Mountains. Quarries have been opened in vertical beds of bituminous sandstone of this formation a mile south of Woodford and also 5 miles southwest of Ardmore.

Production may be expected from the petroleum-bearing sands of the Glenn formation when these sands are found in an unoxidized state beneath gently folded anticlines. It is a question, however, whether oil and gas in commercial quantities can be expected from the Ordovician sands under the same conditions on account of the degree of metamorphism which they have undergone. ${ }^{8}$

\section{Age of the Strata Bengath the Oil Fields}

\section{Loco}

During the examination of the Duncan, Loco, and Healdton fields by C. H. Wegemann in 1914, ${ }^{9}$ Pennsylvanian fossils were found in some of the deeper wells in the Loco gas field and Wegemann suggests that the contact between the Permian and Pennsylvanian lies above the limestone which is found at depths of 860 to $1000 \mathrm{ft}$. (262 to $304 \mathrm{~m}$.) below the surface. ${ }^{10}$ The most productive gas sand (at 700 to $800 \mathrm{ft}$.) may be at the base of the Permian.

\section{Duncan, Lawton, Wheeler}

Although no fossils have been reported from the Duncan or Lawton fields, Wegemann believes that Pennsylvanian rocks underlie both fields, possibly at a depth of $1825 \mathrm{ft}$. $(556 \mathrm{~m}$.), in the former and $1165 \mathrm{ft} .(355 \mathrm{~m}$.) in the latter. At Lawton, the absence of any exposures of Pennsylvanian rocks and the presence of Cambro-Ordovician strata dipping $4^{\circ}$ southeast at a distance of only 5 miles northwest of the field make it probable that pre-Carboniferous, and possibly Simpson or Viola petroleum-bearing strata underlie the field and that from them the petroleum leaked into the Permian beds.

${ }^{7}$ Idem, 8.

${ }^{8}$ David White: Some Relations in Origin between Coal and Petroleum. Journal of the Washington Academy of Science (1915), $\overline{\mathbf{5}}, 189-212$.

${ }^{9} U$. S. Geological Survey, Bulletins $621 b$, c, and $d$, respectively (1915): (b) C. H. Wegemann and K. C. Heald: Healdton Oil Field, Carter County, Oklahoma. (c) C. H. Wegemann: Loco Gas Field, Stephens and Jefferson Counties, Oklahoma; (d) C. H. Wegemann: Duncan Gas Field, Stephens County, Oklahoma.

${ }^{10}$ Idem, Bulletin 621 c, 35. 
Permian strata at Wheeler ${ }^{11}$ extend to a depth of about $900 \mathrm{ft}$., the oil and gas sands occurring at depths of between 700 and $900 \mathrm{ft}$. (213 to $274 \mathrm{~m}$.). The great thickness of blue shales, barren of petroleum, encountered in deep wells in the field indicates that the strata beneath the Permian are probably of Pennsylvanian, Glenn formation, age. It does not appear to be possible to correlate the logs of the deep Wheeler wells with those of the Fox wells.

\section{Fox, Graham}

In the Fox and Graham fields in T2S, R3W and T2S, R2W, respectively, Pennsylvanian fossils have been found by the writer in cuttings from the wells. Crinoid stems have been found in five wells and additional fossils in two wells which have been identified by Dr. G. H. Girty of the U. S. Geological Survey. Crinoids only were noted in Gypsy Oil Co., Mattie Morris No. 1, sec. 28, T2S, R3W at a depth of about 1800 ft. (548 m.); in Plains Oil Co., Bentley No. 1, same section, depths 1956 and $2010 \mathrm{ft}$. (596 and $612 \mathrm{~m}$.); in Okla-Fox Oil Co., Airington No. 1, sec. 7, T2S, R2W, depth about $-2550 \mathrm{ft}$. (777 m.). Fragments of a small Rhombopora (possibly R. Lepidendroides), and possibly a Fenestella brace, were found in material from Gypsy Oil Co., Mattie F. V. Morris No. 1 (Mattie Morris No. 2), sec. 29, T2S, R3W, depth $1930 \mathrm{ft} .(588 \mathrm{~m}$.), and the following fossils were identified by Dr. Girty from a limestone passed through in the Creston Oil Co., G. W. Chaffee No. 1, sec. 2, T3S, R3W, from 1400 to $1430 \mathrm{ft}$. (426 to $436 \mathrm{~m}$.).

Syringopora multattenuata.

Filistulipora carbonaria.

Productus cora.

$F$ usulina related to $F$. cylindrica.

Bryozoa belonging to the genera Stenopora and Polypora.

Crinoid segments.

Heavy, asphaltic oil $\left(19.4^{\circ}-22.0^{\circ}\right.$ G. Bé.) is found in small quantities in the Graham field, Pennsylvanian sands producing at a depth of 2590 to $2725 \mathrm{ft}$. (789 to $830 \mathrm{~m}$.) in sec. 7, T2S, R2W and a Permian sand producing at a depth of $1650 \mathrm{ft}$. ( $503 \mathrm{~m}$.) in sec. 18 of the same township. The deeper oil is of slightly better grade than is the shallower.

Fox has produced enormous quantities of gas from the center of the anticline in sections 28-29, T2S, R3W, and some oil near the crest of the structure in section 29 and on the north side in section 20 . Production is from Pennsylvanian sands, some of which may be continuous under the field, but many of which are in the form of lenses, at depths of 1400 to $2100 \mathrm{ft}$. (426 to $640 \mathrm{~m}$.). No petroleum has" been noted in the "Red Beds" at Fox although the structure in these beds appears to be almost

11 J. H. Gardner: The Oil Pools of Southern Oklahoma and Northern Texas. Economic Geology (1915), 10, 422-434. 
identical with that in the underlying Pennsylvanian rocks. In the next anticline to the west along the Wheeler-Fox line, small production is expected from the Permian at $1100 \mathrm{ft}$. $(335 \mathrm{~m}$.) (30 ft. above the base of the "Red Beds") in sec. 13, T2S, R4W and farther west an oil sand has been found at a reported depth of $520 \mathrm{ft}$. $(158 \mathrm{~m}$.) in sec. 36 , T1S, R5W on the Velma anticline. The oil in the Fox pool is of a better grade, $31.4^{\circ}-34.0^{\circ} \mathrm{G}$. Bé., than that in the Graham field although the principal producing sand appears to be the same in both fields.

\section{Healdton}

In cuttings from wells in the Healdton field, which has a daily production of about $65,000 \mathrm{bbl}$. of oil with an asphaltic base, fossils of Pennsylvanian and also of Ordovician age have been found by the writer. The distribution of the wells and the depths from which the fossils have come prove that the field is composed of a cover of Permian "Red Beds" which do not contain petroleum in commercial quantities, conformably overlying Pennsylvanian (Glenn formation ?) blue shales, thin limestones, and irregular sandstones from which the production comes. Unconformably beneath the Pennsylvanian rocks is a mass of Ordovician limestones and shales which may have the form of a closely folded anticline. This old ridge may be called the buried "Healdton Hills," as during early Pennsylvanian deposition it must have resembled the Criner Hills of today. The Healdton Hills, together with the Criner Hills which are structurally similar, ${ }^{12}$ must have been formed at some time between the close of the Ordovician and the beginning of the Pennsylvanian-possibly at the time of the late Mississippian movements in the Ouachita and Arbuckle Mountains ${ }^{13}$-and must have been subjected to considerable erosion before Pennsylvanian deposition in the region.

A list of the wells from which fossils have been secured follows (see

${ }^{2}$ The Criner Hills are mapped by J. A. Taff: Preliminary Report on the Geology of the Arbuckle and Wichita Mountains in Indian Territory and Oklahoma. U.S. Geological Survey, Professional Paper 31 (1904). There is a remarkable arrangement of anticlines in southern Oklahoma in northwest-southeast lines. One of these lines, in Marshall County, Oklahoma, and Grayson County, Texas, passes through the bend in the Red River near Shay and Preston and contains the Preston anticline and Enos gas field (in the Cretaceous Trinity sand). Two other lines seem to diverge from the Criner Hills, one passing through Wheeler and Fox and Velma, the other through Healdton and Loco. The Graham and Dunean structures may be on still another line. In the lines west of the Criner Hills the axes of the individual anticlines are en échelon to the general trend.

${ }^{13} \mathrm{It}$ is possible that the movement was Lower Paleozoic and comparable to that which has been suggested by the writer in the case of the buried granite knobs of Kansas. American Journal of Science, Ser. 4 (1917), 44, 146-150. 
Fig. 2), the identifications being by Dr. E. O. Ulrich of the U. S. Geological Survey:

\section{Pennsylvanian}

Southwestern Pet. Co., Hartgrove No: 1, NW corner see. 19, T4S, R2W (in white limestone), depth 1960 to $2055 \mathrm{ft}$. (597 to $626 \mathrm{~m}$.).

Producers Oil Co., Jerome Watson No. 16, NE1/4, SE1/4, SE1/4, sec. 15, T4S, R3W, depth $1200 \mathrm{ft}$. (365 m.).

Gates Oil Co., Lizzie Carnes No. 15, E side, NE1/4, SE1/4, same section, depth $1228 \mathrm{ft}$. $(374 \mathrm{~m}$.).

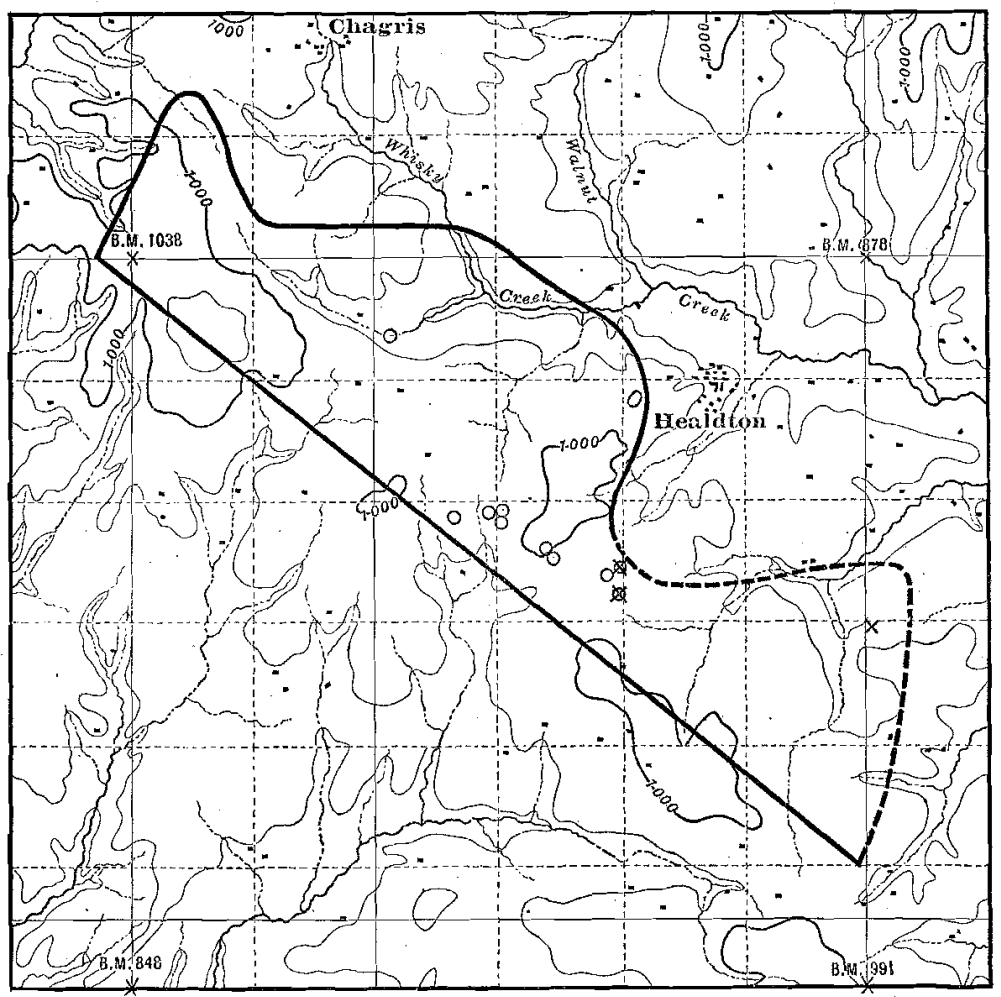

FIG. 2.-MAP SHOWING THE IIMTTS OF PRODUCTION IN THE HEALDTON OIL FIELD. THE LOCA'TION OF THE WELLS FROM WHICH FOSSILS HAVE BEEN OBTAINED ART GIVEN, A cRoss indicating PENNSYLVANIAN, A CIRCLE ORdovician fossils. NOTE THE "DRY HOLE" LINE WHICH BOUNDS THE FIELD ON THE SOUTH.

\section{Ordovician}

1. Hamon and Colcord, D. O. Coffey No. 11, center sec. 15, T4S, R3W, depth 1375 to $1400 \mathrm{ft}$. (419-426 m.).

2. Producers Oil Co., Jerome Watson No. 11, E side SE1/4 same section, depth $1550 \mathrm{ft} .(472 \mathrm{~m}$.$) .$

3. Ruby Oil Co., Ruby-Ingram No. 2, SE1/4, NW1/4 same section, depth 1232 to 1235 ft. (?) (375 to $376 \mathrm{~m}$.). 
4. Magnolia Pet. Co., D. O. Coffey No. 19, NW1/4, SW/4, NW1/4, same section, depth 1184 to $1400 \mathrm{ft}$. (360 to $426 \mathrm{~m}$.).

5. Scivally Pet. Co., Vernon Collins No. 9, SW1/4, NW1/4, NW1/4, same section; depth 1192 to $1200 \mathrm{ft}$. ( 363 to $365 \mathrm{~m}$.).

6. Bullhead Oil Co, A. Daney No. 14, NW1/4, SW14, sec. 4, T4S, R3W, depth 2470 to $2510 \mathrm{ft}$. ( 752 to $765 \mathrm{~m}$.). (Production $48 \mathrm{bbl} .44^{\circ}$ Bé oil 2716 to $2749 \mathrm{ft}$. (827.8 to $837.8 \mathrm{~m})$.$) .$

7. De Sada Oil Co., Vernon Collins No. 5, SE1/4, NE1/4, NE1/4, sec. 16, depth 1156 to $1239 \mathrm{ft}$. (352 to $377 \mathrm{~m}$.).

8. Carter Oil Co., John Carter No. 1, S line, NW1/4, NE1/4, same section, depth $1100 \mathrm{ft} .(335 \mathrm{~m})$.

9. Producers Oil Co., Jerome Watson No. 16, NEY4, SEY $14, \mathrm{SE} / 4$, section 15 , depth $1270 \mathrm{ft}$. (387 m.).

10. Gates Oil Co., Lizzie Carnes No. 15, E side, NE1/4, SE1/4, same section, depth ess than 1329 feet ( $405 \mathrm{~m}$.).

Dr. Ulrich has identified the fossils listed below from (1), the horizon being in the lower third of the Simpson formation on the southern flank of the Arbuckle Mountains, about $1350 \mathrm{ft}$. (400 m.) beneath the base of the overlying Viola limestone in sections near Springer, Carter County. ${ }^{14}$

Plates and columnals suggesting Caryocystites and probably one or two other genera of cystids.

Bythopora n. sp.

Eridotrypa ? n. sp.

Orthis aff. orthambonites and tricenaria.

Plectambonites? sp.?

Maclurea ? n. sp.

Aparchites sp.

Schmidtella sp.

Amphion cf. nevadaensis.

Limestone fragments from (2) were practically the same in lithology. and faunal contents as (1), but contained an ostracod of undescribed genus. Lower Simpson is suggested by material from (4-7) and the same zone or possibly a higher one (upper Simpson) is indicated by crinoid or cystid columnals from (8-10).

The fossils were found in cutitings of blue saindy shale and of limestones and were in a number of instances (wells 4-10) so minute that they were found only by examining the fine cuttings with a high-power lens. Some of the Pennsylvanian fossils at Healdton occur in a very fine oolite.

In three wells (8-10), if the identifications of the "crinoid and cystid columnals" (which were most minute) are correct, production is from Ordovician sands, $109 \mathrm{ft}$. $(33.23 \mathrm{~m}$.) below where the fossils were collected in (8), $100 \mathrm{ft}$. (30.5 m.) below the fossil horizon in (9), and oil sands were encountered below the fossil horizon in (10) although this well

${ }^{14}$ S. Powers: Ordovician Strata beneath the Healdton Oil Field, Oklahoma, Bulletin of the Geological Society of America (1917), 28, 159. 
was abandoned. ${ }^{15}$ No evideno ring sands in the Ordovician rocks has been found in the well logs arrd there is very good evidence to show that the older rocks begin at or just beneath the lowest producing sand. In the A. Daney well in section 4, which is drilling at a depth of $3450 \mathrm{ft}$. $(1051 \mathrm{~m}$.) at the time of writing, "shows" of oil have been reported far below proven Ordovician rocks, but no confirmation of these reports is obtainable. If production is obtained in this well below $2500 \mathrm{ft} .(762 \mathrm{~m}$.) the oil will come from Ordovician rocks, but the possibility of downward migration from the Pennsylvanian will remain. ${ }^{16}$

A number of sands are productive in the Healdton field and while individual sands can be correlated in adjacent wells, no single sand can be traced over the field. The shallower sands, especially in the central portion of the field, at depths of 700 to $1000 \mathrm{ft}$. (213 to $304 \mathrm{~m}$.), are known as the Healdton sands and produce black oil of gravity $27^{\circ}$ to $31^{\circ}$ Bé. In the Northwest Extension the shallow sands appear to merge into a single 100-ft. $(30-\mathrm{m}$.$) sand. In the Southeast Extension deeper sands,$ the deepest of which, with the exception of a lens at $1860 \mathrm{ft} .(567 \mathrm{~m}$.), is $1430 \mathrm{ft}$. $(435 \mathrm{~m}$.), are called by various names and yield green to black oil which is usually of slightly better grade than the oil from shallower sands.

Little is known of the buried erosion surface above the Ordovician limestones and shales. Basal conglomerates are not found, but fine bluish sands composed largely of limestone grains as seen in the cuttings appear to overlie the limestones, and it is in these basal sands and sandy limestones that a large percentage of the deeper production comes. Occasionally the basal sand is barren or missing and these places may be slight rises in the buried Hills. Relief is shown in the old erosion surface along the strike of the field from section $5 \mathrm{~T} 3 \mathrm{~S}, \mathrm{R} 4 \mathrm{~W}$ to section $18 \mathrm{~T} 4 \mathrm{~S}$, $\mathrm{R} 2 \mathrm{~W}$ of over $900 \mathrm{ft}$. $(274 \mathrm{~m}$.), or $180 \mathrm{ft}$. $(54 \mathrm{~m}$.) per mile if the slope were uniform (which is not the case). Across the strike it is not possible to give figures, but a far steeper surface gradient must exist (Fig. 3).

The importance of Ordovician limestones to petroleum geology is that the deep wells in the limestone will be dry and that deep sands are to be expected only on the edges of the field. The Ordovician rocks have, however, a greater significance, for they apparently determined the shape of the field (Fig. 2) which has a sharp southern boundary and three lobes, symmetrically arranged, on the north. A "dry hole" line exists on the south, toward which wells grow small and beyond which, with the exception of three or four four-barrel wells, all wells drilled have encoun-

15. The cuttings were collected by the writer while the wells were drilling and before the oil sands were reached and the depths from which the material came are accurate to within a few feet.

${ }_{16}$ The A. Daney well was shot twice and is producing $48 \mathrm{bbl}$. of $44^{\circ}$ Bé oil (very much lighter oil than any other in the field) from a sand at 2716 to 2749 ft. $(827.8$ to $837.8 \mathrm{~m}$.). 
tered either dry or salt-water sane? asponding to those which produce petroleum north of the line. This lwi may be explained as representing the south face of the Healdton Hills just as today an even line, interrupted by only two faults, represents the southern boundary of the Arbuckle Mountains in Carter County. If the Ordovician strata dip steeply south on the south side of the Healdton Hills, erosion would normally produce a steep, straight south face in hard limestones beneath soft rocks and a more or less undulatory upper surface in the main upturned mass, very possibly sloping gently north (Fig. 3). With the epeirogenic movements at the close of the Permian an uplift would be expected to act most effectively on a buried mountain mass and an isostatic readjustment would diminish the volume of the younger sediments on all sides of an older, buried mass; a movement of either kind producing the same effect: an emphasis of preëxisting topography in the younger rocks.

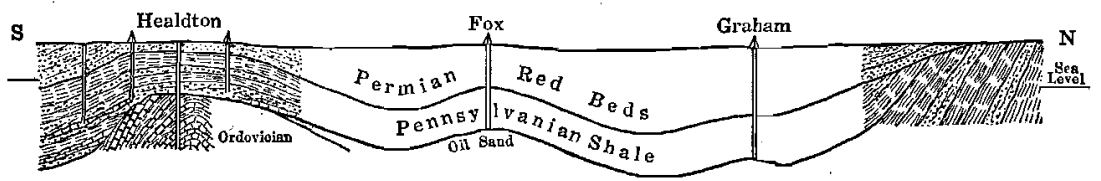

Fig. 3.-Cross-section of. the Healdton, Fox and Wheeler anticlines showing the Relation of the BURied HealdToN Hills, composed of ORdovician strata, to the overlying Pennsylyanian and Permian strata. Section DRAWN TO SCALE (TOTAL LENGTH 21 Miles) WITH A VERTICAL EXAGgERATION $4 \times$.

\section{Conclusions}

Southern Oklahoma fields, with the exception of Fox and Healdton, yield petroleum from Permian strata, the petroleum probably having migrated from Pennsylvanian and possibly in part from older sands. In the Fox, Graham, and Healdton fields, oil is produced from Pennsylvanian sands. Deep tests have shown the absence of any deep petroleum sands at Wheeler and at Lawton, but deep tests have been lacking in the centers of the Loco and Duncan fields.

Healdton presents an example of a mountain-built, probably anticlinal, structure buried beneath sediments of both Pennsylvanian and Permian age, the older mass having determined the presence and the form of the uplift in the younger rocks. It has been shown that the Permian and Pennsylvanian are practically conformable at Healdton, as they are in the Fox and Graham fields on the north, but that the Pennsylvanian was deposited on an upturned mass of Ordovician strata. Oil has been found in only one well in the Ordovician rocks, if the evidence of well $\log$ is accepted, and little Ordovician oil is to be expected. Production at Healdton will be practically confined to the top and sides of the old Healdton Hills in the irregular sands of Pennsylvanian age above the massive Ordovician limestones. 


\section{DISCUSSION}

Wallace E. Pratt, Wichita Falls, Tex. (written discussion*).-The age of the oil in the southern Oklahoma fields, Mr. Powers concludes, is Pennsylvanian, or in part, possibly, pre-Pennsylvanian. In a later paper, ${ }^{1}$ he recognizes the Ordovician age of the small production from the Bullhead A. Daney, No. 14, in the Healdton field. But nowhere does Mr. Powers admit the possibility of oil of Permian age in southern Oklahoma. Yet shallow oil in the adjacent north Texas fields (Electra, Burkburnett, and Petrolia), which are generally conceded to be closely related to the fields of southern Oklahoma in geological aspect, may very well be of Permian age. Dr. Udden has already discussed this question, ${ }^{2}$ noting the organic nature of the limestone outcropping near Electra, together with other evidence that organic material was present if not abundant, originally, in Permian rocks. The Permian rocks in north Texas seem to me, in fact, to be quite suitable in character to have given origin to the oil contained in them; and the oil in them seems to be just the class of oil one would expect, knowing beforehand the character of the oil in, and native to, the underlying Pennsylvanian.

Doubtless the exposed Permian beds in southern Oklahoma are less organic in nature than those across Red River in Texas; probably, as Mr. Powers thinks, all the oil so far obtained in southern Oklahoma is pre-Permian in origin; but in adjacent producing fields within the same geologic province, oil of probable Permian age is being obtained, and it seems quite possible that future development may be rewarded with oil of the same age in southern Oklahoma.

Are the developed fields of north Texas, like Healdton, as described by Mr, Powers, on folds superimposed on older, unconformable, "buried hills," the presence of which fixed the position of the folds in the later rocks, and is there here, as at Healdton, a comparatively shallow limiting depth beyond which petroleum is not to be sought? Unfortunately, the answer to these questions probably cannot yet be made with the secure basis Mr. Powers' data affords for his conclusions on Healdton. Certainly deep holes-more than $2000 \mathrm{ft}$. deep-have not been encouragingly successful in the developed north Texas fields. It is true, also, that limestone is encountered generally below the deepest producing horizons, and several observers have taken the evidence at places to indicate an unconformity over this limestone. There seems to have been no question as to the Pennsylvanian age of the rocks at the bottoms of all the deep holes drilled to date; however, even where unconformity is suspected. The presence of petroleum in north Texas below the deepest producing

* Received Jan. 12, 1918.

1 Sidney Powers: The Healdton Oil Field, Oklahoma. Economic Geology (OctoberNovember, 1917), 12, 594-606.

2 J. A. Udden: Reconnaissance Report on the Geology of the Oil and Gas Fields of Wichita and Clay Counties, Texas. University of Texas Bulletin 246 (1912), 94. 
sands, is, therefore, not unlikely, since farther south in Texas oil is now being obtained from the lowest beds of the Pennsylvanian.

Mr. Powers' data on Healdton is fundamental to any intelligent analysis of the petroleum geology of that field, but it is made public nearly four years after drilling started there, at a time when, apparently, the field is near to the beginning of its decline. Is geology really utilized by the petroleum industry to the extent we like to think? Or to the extent conclusions as important as those Mr. Powers is able to draw make its use seem justifiable? If so, would not the condition, for instance, that the deep production which is so valuable over large parts of Healdton cannot be expected in the very heart of the field, have become generally known long since? Possibly; indeed, all the companies employing geologists have known of this condition in the Healdton field for a longer time than the public. But I suspect that it would have been possible at a very recent date, to have interested more than one large, progressive operator in Healdton acreage, now condemned by $\mathrm{Mr}$. Powers as of no promise for deep production, at prices based on the assumption that the deeper sands would produce there as elsewhere.

W. G. MatTeson, Houston, Tex.-I think that Mr. Powers has given us some very valuable information on the Healdton field, which is of material interest in view of the fact that the Healdton field has passed Cushing in the point of production, and if not leading, stands second only to the new El Dorado field in the point of production of the oil in this country.

Mr. Powers says that the deepest producing sand at Healdton is $1860 \mathrm{ft}$. Within the last 3 or 4 months they have drilled to $2700 \mathrm{ft}$. there and found a sand which is producing very high-grade oil, if I remember correctly, about 42 gravity.

Another very important point brought out by Mr. Powers is the fact that the Pennsylvanian beds and the Permian beds are conformable according to his interpretation. He seems to have based his interpretation upon the gathering of a number of well logs and a very careful study of them, but it seems to me the information furnished by the well logs is really insufficient to justify such an important conclusion. In the first place, the difficulty of interpreting the line of demarcation between the Permian "Red Beds" of Oklahoma and the top of the Pennsylvanian is apparent, for the reason that sometimes the uppermost Pennsylvanian formation has a reddish phase and the line of demarcation is not very sharp.

Mr. Powers says that in the vicinity of the Arbuckle Mountains the basic Permian consists of conglomerate of limestone. As we proceed in a southerly direction, however, that conglomerate disappears and the base of the Permian consists generally of a reddish clay. In fact, the field evidence, as one makes a study at Healdton, indicates the greater probability of an unconformity between the Pennsylvanian and the Permian formations.

7or. IIx -37 . 